\title{
Potential Use of AREL in English Song Analysis to Improve Argumentation Skills and English Proficiency
}

\section{Muhammad Iqhrammullah ${ }^{1 *}$, NatasyaZuelda ${ }^{2}$}

\footnotetext{
* Correspondence:

m.iqhram@oia.unsyiah.ac.id

1. Department of Chemistry, Syiah

Kuala University Darussalam, Banda

Aceh 23111, Indonesia

2. Department of English Language

Education, State Islamic University of

Ar-Raniry Darussalam, Banda Aceh

23111, Indonesia
}

Received: 25 September 2018

Revision: 16 November 2018

Accepted: 30 December 2018

Published online: 20 March 2019

\begin{abstract}
This study attempts to assess the potential use of AREL in English song activities as a learning method to improve the students' ability in argumentation and English proficiency. AREL-stands for Assertion, Reason, Evidence, and Link back has long been introduced as a basic structure for argument construction. Learning AREL has been a major challenge for the beginner debaters, not to mention their constraints in English proficiency. The data received in this study were analysed by means of frequency, percentage and standard deviation. The students highly believed that the method used in this study was interesting ( $\bar{x}=3.79$ $\mathrm{SD}=0.860)$ and comfortable $(\bar{x}=3.86 \mathrm{SD}=0.639)$, in which it indicates the enjoyable learning process and the absence of the students' anxiety. Furthermore, this method was able to give a quick comprehension $(\bar{x}=4.00$ $\mathrm{SD}=0.654$ ) on AREL, where applying AREL in song analysis was easier for the students, thus allow the students to gradually step up onto the real argumentation. That could be observed by the average test score where students obtained higher score for analysing song with AREL $(\bar{x}=80)$ than for making real argumentation with AREL $(\bar{x}=70)$. However, in order to make this method effective, the students' attendance was a mandatory. Though no test on English proficiency conducted, nevertheless most of the students agreed that this method helped them improving their English proficiency, which included vocabularies $(\bar{x}=4.64 \mathrm{SD}=0.610)$ and figurative language $(\bar{x}=4.50 \mathrm{SD}=0.500)$ competencies.
\end{abstract}

Keywords: English proficiency, song, critical thinking, competitive debate, senior high school 


\section{Introduction}

Positive youth development has become a concern for international and national communities. The role of youth is taking a big part in global development. One example is the formation of United Nations Major Group for Children and Youth (UNMGCY), a UN-mandated advocacy group, focuses on facilitating the voice of children and young people. ASEAN Work Plan on Youth 2016-2020 has been set in ASEAN Senior Officials Meeting on Youth in 2016, prioritizing on youth entrepreneurship, youth employment, youth awareness, youth volunteerism and leadership, and youth resilience. These young people, however, should be given a platform to grow their potentials. According to some studies (Agustina \& Bahrani, 2016; Husnawadi \& Syamsudarni, 2016; Parcher, 1998), competitive debate could be an empowering platform for young people to hone their critical thinking and communication skills, as well as to boost their aspiration, confidence, and cultural awareness (Akermanand Naele, 2011).

In the previous study, Iqhrammullah and Zuelda (2017) reported a set of significant benefits of competitive debate for Aceh students, they are: improvement of English proficiency, critical thinking, problem solving, logical thinking, teamwork, self-confidence, networking, social awareness, and competitiveness. Unfortunately, only some schools are good in competitive debate, showing the lack of even distribution of competitive debate proliferation in Aceh, a province in Indonesia. For the most part, Aceh students are lacking in English proficiency and the ability of argumentation. Nudzran, a competitive debate observer in Aceh, confirmed the two weaknesses are common problems for Aceh students. As a complement, Fitri who carries out a debate course in Bireuen (a regency in Aceh), found argumentation ability is the major obstacle in developing students' debating skills.

A common and widely-used structure to construct an argument is AREL - stands for Assertion, Reason, Evidence, Link back (Muhammadin et al., 2014). An argument, in general, is a statement logically supported by reasons and facts. In contrary, a statement without supporting reasons and proofs is considered as an assumption and will be less credited in competitive debate adjudication. Nudzran conveyed that AREL can be used, not only in competitive debate, but also in our daily communication. Apart of AREL is being important and beneficial for students' academic attainment, it takes a long time to teach AREL to the students, and even some will still be confused with the structure. "Usually it takes 3-5 sessions regarding AREL material before the students really comprehend. Only some of the students eventually use it when constructing arguments," said Nudzran.

One of the dilemmas in teaching competitive debate is English proficiency. It is not necessary, since debate is adjudicated based on how logic and deep an argument is. However, to convey the argument, the debaters must use English as some debate competitions are held in English. As for the secondary school students, there is the biggest and the most prominent debate competition internationally held once a year, namely World School Debating Championship (WSDC). To choose 4-5 Indonesian representatives to compete in WSDC, a national debate competition was held by Indonesian government, namely National School Debating Championship (NSDC). Due to its popularity, competitive debate is now strongly affiliated with English, though there is the same annual Indonesian language debate competition (Lomba Debate Bahasa Indonesia - LDBI).

Seeing how English proficiency is not far less important than argumentation ability, we developed a learning method that could solve the two problems together. Using song in teaching English has been proven to be effective. Song could offer a relaxed and fun learning atmosphere so that it could help the students to quickly learn English vocabularies and how the vocabularies are pronounced (Lee \& Li, 2016; Phisutthangkoon \& Panich, 2016). Despite listening to the song, Millington (2011) suggested that song could be used in various modified ways to fit the teacher's expectation. Therefore, by combining both song and AREL together, we expect these followings:

1. An enjoyable and interesting learning process thus will motivate students to learn more.

2. Making AREL to be easily understood and familiar for the students.

3. Improving students' English proficiency by recognizing and analysing figurative meaning in the lyrics.

\section{Review of the Literature}

\subsection{Competitive Debate}

Debate is a platform of idea and critical thinking contest, where one side is arguing with the other side under a certain decided topic. Akerman et al. (2011) describe debate as an oral exchange of arguments between two assigned sides (government and opposition). Many studies have been conducted to evaluate the benefits of competitive debate in 
academic context (Alasmari \& Ahmed, 2013; Condon \& Doody, 2012; Ramlan et al., 2016). Pradana (2017) reported that employing debate in a classroom could contribute to the student's character building, where they become more confident in delivering their own point of view. In our previous study (Iqhrammullah \& Zuelda, 2017), competitive debate was found to benefit in English proficiency, critical thinking, problem solving, logical thinking, teamwork, self-confidence, networking, social awareness, and competitiveness.

Prominent English debate competition in Indonesia, National School Debating Championship (NSDC), adopts Asian Parliamentary debating style. In Asian Parliamentary system, the two team are assigned into two benches, government and opposition, where each of the bench consisted of 3 speakers. Each of the speakers conveys their arguments to the adjudicators during the 7 minutes substantive speech. While the adjudicator may include the rhetoric manner (eye contact, clarity, intonation, etc.) in the adjudication criteria, ideally the adjudicators will weigh the adjudication on the argumentation. Therefore, apart from being persuasive, conveying an argument in the most possible structured manner is essential in order to make the arguments to be more impactful and understandable.

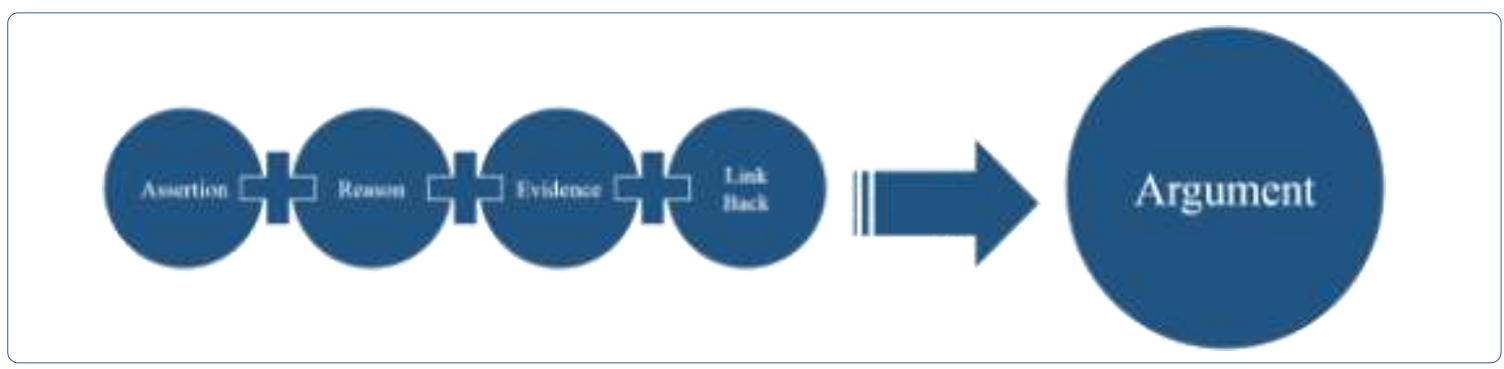

Figure 1. AREL format diagram, where an argument consisted of assertion, reason, evidence and link back

In constructing an argument, AREL is oftenly employed (Adimarta, 2015; Rohmatika \& Syamsuddin, 2014; Simbolon \& Ginting, 2013). AREL stands for Assertion, Reason, Evidence, Link back, a common argumentation format for senior high school students in Indonesia, especially in Aceh (Fig. 1). Assertion is a statement or a claim which has not yet been proven through further reasonable and logical analysis. In debate competition, debaters must avoid to only have assertion in their case and present a complete argument instead (Sonnreich, 2012). Therefore, for every assertion, reason and evidence (if available) must be provided. Reason is an analysis as to why the assertion is likely to be true under a set of logical and reasonable explanations. Besides, reasoning analysis is also used to interpret the data given in evidence. Evidence can be in a form of statistical data (number of violations, rate of economic growth, etc.) or general knowledge (that the war causes casualties that people fear the death, etc.). While Evidence is something that has already been available as what it is, reason involved more analytical process, and sometimes used to interpret the information in the Evidence. It is necessary for the debaters to emphasize the evidence, otherwise they will not receive full credit from the adjudicator. Meanwhile, for Link back, it is used to restate the claimed after being proven by reason and evidence. Link back is meant to remind the adjudicator and audience that the analysis was made to prove the claim.

\subsection{Song Lyrics Analysis}

Song is a collection of words sung by human voice and accompanied by musical instruments with distinct and fixed pitches and patterns. Words in a song, are called lyrics, which include a series of verses. Lyrics can be in a complex structure, consisted of long verses, or in a simple structure which can be consisted of 1 or 2 verses. Moreover, songs have become a widely-consumed entertainment, especially for the teenagers. Due to this fact, songs have been employed as a solution in foreign language learning process. Many researches have proven that songs can give a more relaxing learning environment and improve learning motivation (Aguirre, Bustinza, \& Garvich, 2016; Conesa \& Rubio, 2015; Kuśnierek, 2016). As reported by Shen (2009), songs are able to facilitate English language teaching in listening, speaking, and creative writing activities. In addition, songs could promote different cultures and language awareness which are crucial for language learning.

Context of where and why the song was created is important to know because song lyrics often consisted of implicit messages that are correlated with the context (Kuśnierek, 2016). These implicit messages are figurative language which the meaning cannot be literally interpreted, as opposed to literal language which uses explicit interpretation. In 
Hariyanto's report (2017), for instance, he found that the lyrics in Firework song (sung by Katy Perry) consisted of various types of figurative language such as simile, metaphor, hyperbole, affiliation, symbolic, paradox, and personification. In the lyrics, words 'do you ever feel like a plastic bag', is an example of symbolic figurative language used to describe a person who does not have a strong motivation and surrender to the situation.

Comprehension on figurative language has a strong correlation with English proficiency (Aleshtar \& Dowlatabadi, 2014). Explicitly teaching about figurative language could improve student's attentiveness, the ability to recall the vocabularies and comprehension (Doiz \& Elizari, 2013). In song lyrics, understanding the figurative language is quite essential to comprehend the whole meaning of a song. Comprehension on this figurative meaning requires reasoning process that could intrigue the individuals to think (Doiz \& Elizari, 2013). Implementation of understanding figurative meaning in Aceh secondary schools, however, still face many difficulties (Marliani, 2018). Therefore, in this study, the researchers expect the lyrics analysis with AREL template to help the students to acquire a sustainable improvement in English proficiency, by improving their competencies in figurative language.

\subsection{Learning Motivation}

English can be a difficult subject for non-native speaker, especially in English as Foreign Language (EFL) context where the language is not naturally available outside the classroom. To make an impactful learning process, the students are required to possess strong motivation. Motivated students show enthusiasm and full concentration on the taught materials, and they are able to affect other students to be motivated through group discussion (Al Othman \& Shuqair, 2013). Learning motivation can come from various factors. There are intrinsic and extrinsic motivational factors. Intrinsic factors are what the learning process offers to the students, for example, a chance to get involved, curiosity, challenge, and social interaction. Meanwhile, extrinsic motivational factors include compliance, recognition, competition, and work avoidance.

Students' interest in learning can also be indicated by their attendance. When the students lose interest in the class subjects, they are more likely to skip the class. Many studies had found the significance of the negative effect of absteenism towards the academic performance (Berman et al., 2018). Teachers should pay great attention to this matter, as it affects students' performance in the school (Mahdiloo \& Izadpanah, 2017). Thus, creative teaching methods (such as song lyrics analysis) are required to make the students more interested in learning (Nadera, 2015). The studying interest can also be indicated by students' willingness to initiate group discussion with their seniors (Mehrvarz Bahambari \& Rahimy, 2016). The researchers expect the treatment of this study would not only give a relaxing and comfortable learning environment for the students, but also offer a learning motivation for the students.

\section{Methodology}

This study used both qualitative and quantitative approaches to accommodate a holistic evaluation for the used learning method. Student engagement to the method will be presented in qualitative description to elaborate the student's per-session progress. To support the objectivity of this study, the researchers analysed students' opinion with five-item Likert scale questionnaire.

\subsection{The Participant and Setting}

This study took place in SMA N 1 Banda Aceh, from August $11^{\text {th }}-25^{\text {th }}, 2017$. The 14 students who underwent this debating practice are members of Jeumpa Puteh English Club. Within the span of two-weeks, the 4 sessions was conducted. The students were $1{ }^{\text {st }}$ graders, thus had a bare knowledge in argumentation, especially AREL.

\subsection{Design of the Study}

Using song in AREL material had never been studied before, making this as the first time it was tested. Each session will be consisted of different difficulty levels of the materials - the second session had more difficulty than the first one, and so on. Homework was given in each session to engage the students with the taught materials. 
Table 1. The method design of understanding AREL through song analysis that consisted of per-session topics

\begin{tabular}{|c|c|c|}
\hline & Material & Activity Description \\
\hline & $\begin{array}{l}\text { Listening to a } \\
\text { song }\end{array}$ & $\begin{array}{l}\text { Students were asked to listen to } \\
\text { a prepared song. They were } \\
\text { intrigued to figure out the title } \\
\text { and the singer. }\end{array}$ \\
\hline & $\begin{array}{l}\text { Learning the } \\
\text { figurative } \\
\text { meaning of the } \\
\text { lyrics }\end{array}$ & $\begin{array}{l}\text { Students were asked to } \\
\text { highlight some key words that } \\
\text { contain figurative meaning and } \\
\text { discuss them together. }\end{array}$ \\
\hline $\begin{array}{l}\bar{\Xi} \\
\text {.0 } \\
\text { 心 } \\
\tilde{\omega}\end{array}$ & $\begin{array}{l}\text { Learning the } \\
\text { song's stories }\end{array}$ & $\begin{array}{l}\text { Every song has a story; how } \\
\text { was made, what motivated th } \\
\text { songwriter to write the son } \\
\text { how many awards the song ha } \\
\text { won, etc. The students we } \\
\text { learning this through th } \\
\text { teacher's explanation. }\end{array}$ \\
\hline
\end{tabular}

Presentation of Three students were randomly the previous chosen to present their homework homework in front of the class. Before starting the presentation, the songs they had chosen were played aloud.

Introduction of The definition and the AREL (part I) mechanism of AREL were explained by the teacher. Simple examples were given to better give understanding to the students.

Introduction of The students were asked to the use of AREL analyse the meaning of the in song analysis song using AREL structure. A leading question "what does the song teach us about?" was given to help the students analyse the song. Examples were given to better give understanding to the students.

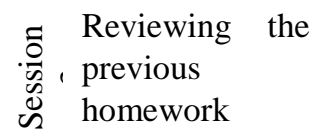

\begin{tabular}{|c|c|}
\hline Task and Homework & Objective \\
\hline $\begin{array}{l}\text { Students } \\
\text { assigned to choose } \\
\text { their own favorite } \\
\text { song and make the } \\
\text { following description } \\
\text { about it: }\end{array}$ & $\begin{array}{l}\text { 1. To introduce the music } \\
\text { into class discussion. }\end{array}$ \\
\hline $\begin{array}{l}\text { 1. Song's identity } \\
\text { (title, } \\
\text { songer, }\end{array}$ & $\begin{array}{l}\text { pronunciation to improve } \\
\text { students' } \\
\text { proficiency. }\end{array}$ \\
\hline
\end{tabular}
released date)

\section{Lyrics}

3. The type of song (production history, songwriter's

motivation, awards, and etc.)

The students were given a task to analyse the meaning of the song using AREL structure out of the song they had chosen for their previous homework.

The students were given homework to search for another song, then analyse it with AREL structure.

The students were given a task to remake their homework
3. To lead the students on how to understand the figurative meaning from the lyrics.

4. To intrigue students' curiosity over the song they like. It helps them to improve their critical thinking.

1. By reviewing the previous homework, the students will keep engaged to the previous materials and its continuation.

2. To give basic understanding regarding AREL.

3. To introduce the use of AREL to analyse the song's meaning.

1. By reviewing the previous homework and material, we expect the 
Revisiting the The teacher explained this introduction of followings:

the use of AREL

in song analysis

1. What is an argument and how it is different from an assumption.

2. How AREL could be used to construct an argument and why it is necessary to follow such structure.

Introduction of The teacher explained how to AREL (part II)

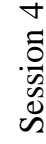

Revisiting The teacher gave clues for the AREL materials students to remember AREL materials by asking questions like, "what is argument? How is an argument different to an assumption?" and "why do we need AREL in argumentation."

Evaluation test The teacher gave two kinds of questions, one was figuring out the meaning of a song $(\mathrm{Q} 1)$ and the other one was justifying a statement (Q2), both had to be in AREL. Both questions need to be answered in less than one hour. by adding more "reasons" in each of their AREL structure groups. The task answers were then reviewed by the teacher.

The students were given a homework to continue improving their task answers and make the elaboration in the paragraph form. students to keep engaged to the previous materials and its continuation.

2. By introducing the AREL (part II), we expect the students to uplift their argumentation ability.

1. By revisiting previous materials, we expect the students to fully understand the most basic knowledge argumentation.

2. Evaluation test is used to evaluate students' ability and their improvement throughout the sessions.

\subsection{Instruments}

Instruments used in this research were individual assignment and evaluation test results, questionnaires, and nonparticipant observation. Individual assignment and evaluation test results were used to measure the students' comprehension on the AREL technique and its use in English song lyrics analysis. Meanwhile, the students' attitude on the learning method were assessed by the questionnaires (motivation, learning benefit, difficulty and suggestion for improvement) and non-participant observation.

\subsection{Data Collection}

After the evaluation test, the results were scored as in Table 2, and converted to 0-100 scale. All the data were then expressed in mean and standard deviation using EXCEL. 
Table 2. Evaluation test score interpretation

\begin{tabular}{|c|c|}
\hline Point & Description \\
\hline 0 & No answer. \\
\hline 1 & AREL is incomplete. \\
\hline 2 & AREL is misplaced. \\
\hline 3 & Points of AREL are disintegrated (correlation between A and R). \\
\hline 4 & The evidence has no correlation with the reason. \\
\hline 5 & $\begin{array}{l}\text { The evidence is potentially correlated but without further explanation (figurative } \\
\text { meaning needs to be explained). }\end{array}$ \\
\hline 6 & AREL is complete, integrated, the evidence is explained but the link back is lacking \\
\hline 7 & AREL is flawless. \\
\hline$+0,5$ & $\begin{array}{l}\text { If one AREL analysis contains more than } 1 \text { reason, the evidence supporting the } \\
\text { reason is lacking in explanation. }\end{array}$ \\
\hline+1 & If one AREL analysis contains more than 1 well-elaborated reason. \\
\hline$+0,5$ & $\begin{array}{l}\text { If the students made another AREL analysis that is complete, integrated, although } \\
\text { still lacking in evidence explanation and link back. }\end{array}$ \\
\hline+1 & If the students made another flawless AREL analysis. \\
\hline
\end{tabular}

\subsection{Data Analysis}

Students' self-rating score from the five-item Likert scale questionnaire was analysed and calculated for the mean and standard deviation and interpreted into five levels as follows:
4.21-5.00 = very high
$1.81-2.60=$ low
$3.41-4.20=$ high
$1.00-1.80=$ very low
$2.61-3.40$ = fair

\section{Results and Discussion}

\subsection{Studying Interest}

The students were quite active during the class, they could follow the lesson very well. The teacher engaged the students through questions and the students answered them actively. Giving examples that based on things they daily encounter (e.g. their friends' physical look or school activities) could help the students actively participate in the class. Hoogerheide, Loyens, and van Gog (2016) reported that example-based learning method could effectively help the student understand learning materials. During the class, the students were eager to have an active discussion with the senior students as it was encouraged in this learning method. In addition, they seemed to be happy when listening to the songs, especially when they recognized the song. Finding their friends shared the same favourite song also made the students become more interested. This shows how the method could be appealing for the students to learn more. Feeling of happiness and active participation in the class could be the indicator of students' learning interest (Djamarah \& Zain, 2002). 


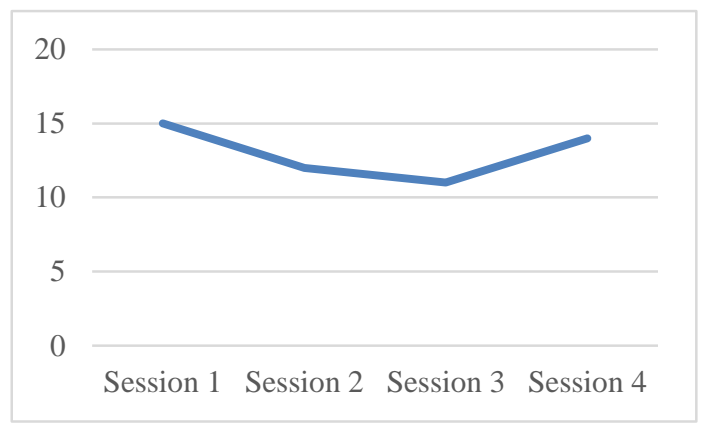

Figure 2. Students' per-session attendance

The students' interest in this learning method could also be assessed by their attendance. According to Renninger, Sansone, and Smith (2004), the students with less interest will have a little willingness to attend. Figure 2 shows the changing of students' attendance per-session, indicating that this learning method could attract the students to stay in the English club. In SMAN 1 Banda Aceh, participating in an extracurricular activity is optional. It is a challenge to make the students stay interested to keep participating in the English club, more importantly to improve their skills for competitive debate. During this study, only one student quitted from the club because she wanted to join another extracurricular activity. Some few students, however, did not fully attended the 4 sessions so that affected their performances in the evaluation test.

Table 3. The student's opinions regarding their studying interest in this learning method

\begin{tabular}{llrll}
\hline No. & Questions & $\bar{x}$ & SD & Level \\
\hline 1 & $\begin{array}{l}\text { I am interested to study AREL, even before } \\
\text { being taught with this learning method. }\end{array}$ & 3.21 & 0.773 & Fair \\
2 & $\begin{array}{l}\text { I am more interested to learn AREL with this } \\
\text { method. }\end{array}$ & 3.79 & 0.860 & High \\
3 & $\begin{array}{l}\text { Learning AREL with this method makes me } \\
\text { feel more comfort. }\end{array}$ & 3.86 & 0.639 & High \\
4 & $\begin{array}{l}\text { This method makes me interested to learn } \\
\text { AREL out of the session. }\end{array}$ & 3.43 & 0.728 & High \\
\hline
\end{tabular}

Table 3 shows students opinion regarding their interest to learn AREL structure through song analysis. Students in fair level ( $\bar{x}=3.21 \mathrm{SD}=0.773)$, felt they are interested in studying AREL even before introduced to this method. The students felt they were highly more interested in learning AREL with this method rather than the usual method $(\bar{x}=3.21$ $\mathrm{SD}=0.773$ ). A larger group of students felt the method was comfortable with $\bar{x}=3.86 \mathrm{SD}=0.639$. Phisutthangkoon and Panich (2016) also found in their study that English song activities could provide a comfortable and enjoyable way of learning. In the practice session, the students were intrigued to learn AREL out of the session ( $\bar{x}=3.43 \mathrm{SD}=0.728$ ). The students' eagerness to learn AREL material apart from the session schedule is an indicator of learning interest (Djamarah \& Zain, 2002). It shows how this learning method had successfully engaged and motivated them to learn AREL.

\subsection{Learning Benefit}

The students' improvement in each session was observed through tasks and homework. At the end of the first session, the students were assigned to do little research in the internet regarding their favourite songs. This activity was important to intrigue their curiosity over the song which was expected to increase the engagement with the students. The students felt this first assignment was easy for to follow, even most of them seemed passionate. Nevertheless, some students found this assignment new to them because previously they had never been searching for as many 
details as in this assignment, especially about the songwriter and the genre. Such information used to be ignored by the students, which was common in their school environment. This attitude could possibly block students' ability to be curious on discovering new things, including new ideas that may support their argumentation. Therefore, the factor to intrigue students' curiosity could also be a major consideration when applying this method.

Table 4. AREL used in analysing an English song titled Hall of Fame sung by The Scripts ft. Will I Am

\begin{tabular}{|c|c|}
\hline AREL & Description \\
\hline Assertion & It teaches us to not giving up. \\
\hline Reason & Describing that it is possible for us to be strong. \\
\hline Evidence & $\begin{array}{l}\text { The lyrics state a fictional monster, 'King Kong' which is a depiction of powerful strength and } \\
\text { significantly huge physical size. }\end{array}$ \\
\hline Reason & Describing that no obstacle is too big. \\
\hline Evidence & $\begin{array}{l}\text { Words 'world', 'war', 'clock (time)', 'mountain', 'rock', 'distance', 'mile' and 'hell' in the } \\
\text { lyrics, were used to depict how big the obstacles and the troubles that could come up while } \\
\text { pursuing our dreams. Although they are big, we can always beat them. }\end{array}$ \\
\hline Link Back & $\begin{array}{l}\text { Because the lyrics tell us that we can be strong and no obstacle is too big, so the song teaches us } \\
\text { for not giving up. }\end{array}$ \\
\hline
\end{tabular}

After the teacher's explanation on how AREL can be used to analyse a song, a task was given to test their ability to analyse the song that they had picked before. However, the students' answers showed that they had not understood AREL. There were two common problems they had; 1) the lack of AREL comprehension and 2) the incapability to interpret the lyrics. The students were not able to understand and distinguish "Assertion, Reason, Evidence and Linkback" of the AREL structure (Sonnreich, 2012). One student, for example, confusedly wrote the lyrics in AREL structure. Another student made assertion in an unnecessary long sentence, in fact, the "assertion" needs to be short and firm. For instance, the student wrote "the lyrics teach us to be brave because nothing can stop us from achieving our goal," this assertion was considered inappropriate because the assertion should only include claim without necessarily prove why it was true. Therefore, the corrected assertion was "the lyrics teach us to be brave." It is important to distinguish assertion and reason, thus the students can have a better structure in their argumentation. Afterwards, the assertion can be followed by reason and evidence. Then, it would be clear that reason is used to prove the claim (assertion) and the words in lyrics (evidencelexample) are used to support the reason. The example of AREL with two-layer argument style used in analysing song lyrics can be seen at Table 4.

The other basic problem was that the students had not enough vocabularies making them hard to interpret the lyrics. Having this activity may help the students to get introduced with new vocabularies, especially when they have illustrative meaning so that the students were required to be attentive (Chen \& Lai, 2011; Doiz \& Elizari, 2013). The teacher was required to explain the possibility of illustrative language to be found within the lyrics. In addition to that, the students might had been familiar with some of the vocabularies; however, there was a tendency of the students to only explicitly interpret the lyrics, including the illustrative language. Unfortunately, this leads the student to falsely interpret the whole meaning of the song. The two problems concluded how the students were not ready to move to the other topic which was why revisiting AREL and giving personal feedback were done. Giving elaborated feedback to the students could help them increase their academic performance (Finn, Thomas, \& Rawson, 2017).

The following assignments were done well by the students, although some students still had a problem to point out evidence and basic understanding regarding the difference between "assertion, reason, evidence, and link-back." This shows how the basic understanding of AREL is the hardest one to learn, and therefore increasing the efficiency of learning the basic is important. 


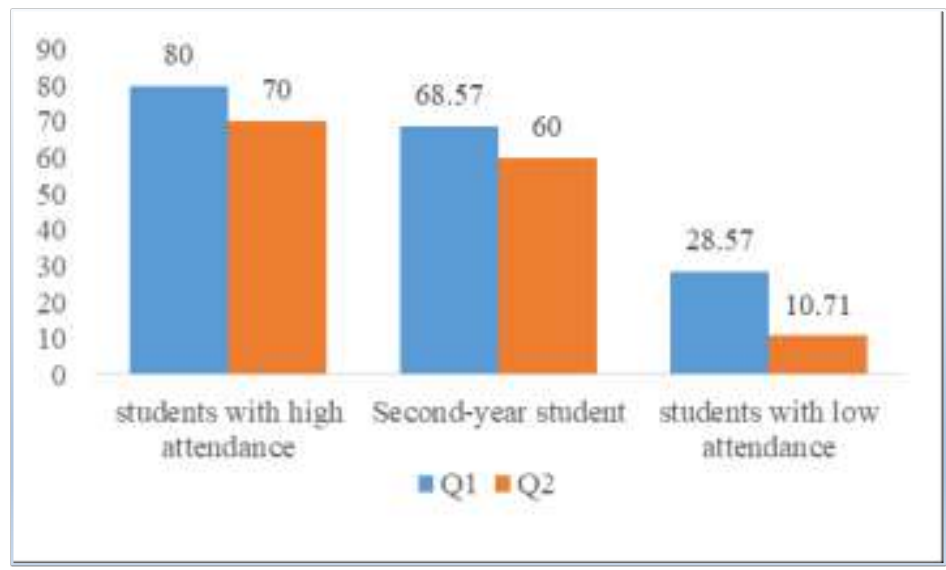

Figure 3. Students' evaluation test result: first-year student with high attendance (Group A), second-year student (Group B), first-year student with low attendance (Group C).

Evaluation test was conducted in the final session to test the students' capability improvement in AREL comprehension. In this evaluation test, the second-year students were invited to join the test, even though they were not actively participating during the sessions. The students were also divided into three groups: first-year students with high attendance (Group A), second-year students (Group B) and first-year students with low attendance (Group C). Each student needed to solve two kinds of question, one was analysing the story of a song (Q1) and the other one was justifying a statement that "studying in school is important" (Q2), both had to be in AREL. As shown in Figure 3 , the evaluation test result demonstrates this learning method affected students' learning process to comprehend AREL.

Group A has the highest average test score $(\mathrm{Q} 1=80$ and $\mathrm{Q} 2=70)$ compared to the other groups. Group B was never taught in this learning method gained lower average score $(Q 1=68.57$ and $Q=60)$, though they had more than a yearlong competitive debate experience. Meanwhile, Group C gained the lowest average score $(\mathrm{Q} 1=28.57$ and Q2=10.71). This result signifies this learning method had positively affected the student's learning process in understanding AREL.

One more interesting fact is, the whole students' average score was higher in Q1 compare to Q2, indicating the use of AREL in song analysis is easier than in "the real" argumentation. In song analysis, it is easy to identify the evidence because it is stated in the lyrics. What the students need to do is to look out the lexical units or phrases in the lyrics that can be associated to prove their statements. As opposed to Q2 case, the students had a difficulty finding out the evidence thus unable to justify their statement. The low difficulty of this learning method could be a good transition for the students to implement AREL in argumentation. This learning method is a positive transfer for the students to learn argumentation skills (Mangal, 2002). Though Group A's score in Q2 is lower than Q1, they performed better in Q2 than Group B did.

Weak correlation between assertion and reason could still be found in the few test answer of the students in Group A. The students were unable to give accurate reason as to why the claim (assertion) is correct resulting in flawed logic. Some of the other students in Group A had problems with providing explanation for the figurative meaning in the evidence. Providing well-elaborated evidence was also a common problem for Group B students. This lacking indicates the students' limited understanding regarding the figurative language. In this study we did not stress the students to focus on the figurative language, thus can be understood why some of them were lacking in that part. However, it is interesting to see that the students were trying to figure out the illustrative meaning of the lyrics. For instance, the students associated phrase "tongue of old" in the lyrics as an "old grudge" which is possibly inaccurate. This indicates that, by this method, the students were intrigued to analyse the figurative meaning in the lyrics. Meanwhile, for the students in Group C, they had a common problem in understanding AREL, in which most of the points (assertion, reason, evidence and link back) were misplaced. This is evident where skipping class could affect 
students' performance negatively. Therefore, it is necessary for the students to follow all the sessions so that they are able to acquire the benefits this method offered.

Table 5. The student's opinions regarding the benefits of this method

\begin{tabular}{llrll}
\hline No. & Questions & $\bar{x}$ & SD & Level \\
\hline 1 & $\begin{array}{l}\text { I have understood AREL before learning in } \\
\text { this method. }\end{array}$ & 2.64 & 1.042 & Fair \\
2 & $\begin{array}{l}\text { Learning with this method makes me easier } \\
\text { to understand AREL. }\end{array}$ & 3.86 & 0.742 & High \\
& $\begin{array}{l}\text { This method helps me to understand the use } \\
\text { of AREL in competitive debate. }\end{array}$ & 0.00 & High \\
4 & $\begin{array}{l}\text { This method helps me to understand the use } \\
\text { of AREL out of competitive debate. }\end{array}$ & 0.71 & High \\
5 & $\begin{array}{l}\text { This method helps me to improve } \\
\text { vocabularies. }\end{array}$ & & 0.64 & Very High \\
6 & $\begin{array}{l}\text { This method helps me to understand } \\
\text { figurative language in English. }\end{array}$ & 0.50 & Very High \\
\hline
\end{tabular}

The students' opinion regarding how this learning method had benefited them in understanding AREL is shown in Table 5. A fair number of students $(\bar{x}=2.64 \mathrm{SD}=1.042)$ felt they had understood AREL before being exposed to this learning method. This indicates that the students were not confident of their understanding on AREL, where it was perceived as something foreign. The method used in this study could be a strategic learning approach because it made the students understand that AREL can be used for multiple purposes when explaining something. Using AREL in daily basis will make the students become familiar with the template, thus they will not require much effort to elaborate an argument. This was confirmed by the students' answer, where they gave a high-level ( $\bar{x}=3.86 \mathrm{SD}=0.742)$, felt this method had made them easier to learn AREL. The students believed that in a high-level, this method had helped them to understand AREL both inside $(\bar{x}=4.00 \mathrm{SD}=0.654)$ and outside $(\bar{x}=3.71 \mathrm{SD}=0.881)$ the competitive debate activities. Most of the students agreed that this method helped them improve their English proficiency, which included vocabularies $(\bar{x}=4.64 \mathrm{SD}=0.610)$ and figurative language $(\bar{x}=4.50 \mathrm{SD}=0.500)$. These indicated that using AREL to analyse English song lyrics would help students both in learning AREL and English at the same time.

\subsection{Difficulty and Improvement}

Table 6. The student's opinions regarding the difficulty and potential improvement of this method

\begin{tabular}{llrll}
\hline No. & Questions & $\bar{x}$ & SD & Level \\
\hline 1 & I think the homework is too difficult. & 2.79 & 0.940 & Fair \\
2 & I have difficulties to comprehend the lyrics. & 2.64 & 1.172 & Fair \\
3 & Group discussion helps me to learn AREL. & 4.00 & 0.655 & High \\
4 & I need deeper explanation regarding AREL. & 4.07 & 0.704 & High \\
\hline
\end{tabular}

Table 6 shows the students' opinion regarding the difficulties they had during the sessions and suggested improvements to design a better learning method. The students fairly believed the homework was too difficult for 
them $(\bar{x}=2.79 \mathrm{SD}=0.610)$. The students also had a fair level of agreement that the lyrics were difficult to understand $(\bar{x}=2.64 \mathrm{SD}=1.172)$. These prove that homework and lyrics comprehension were not the major difficulty for the students to learn in this method. This can be understood since the homework was given in a gradual difficulty level, thus easy to catch up. Regarding the lyrics, most of the songs were selected based on the students' preferences that they had been familiar with, thus making them easily to be understood. It is important to keep the difficulty level low, so it can reduce the degree of anxiety. According to Kakkar (1993), the absence of worry could increase a student's mastery of the taught materials.

The students were encouraged to make study groups outside the session. The students felt the group discussion could help them to learn better about AREL ( $\bar{x}=4.00 \mathrm{SD}=0.655)$. This could be a good suggestion to include group discussion in the future method design. Moreover, the students highly believed that $(\bar{x}=4.07 \mathrm{SD}=0.704)$ further explanation regarding AREL would help them in this learning method. To develop a student's thinking capacity, one should initially possess adequate knowledge regarding AREL (Mangal, 2002). Group discussion could help a student to overcome the adequacy, therefore the opportunity to have discussions is important to be provided. Additionally, discussion could have many benefits, especially to make students becoming more attentive and actively engaged in the learning process (Brookfield \& Preskill, 2012).

\section{Conclusion}

To draw conclusion from this study, the authors referred to the three initial expectations. They are:

1. An enjoyable and interesting learning process. The students seemed to be enjoyed and interested in the learning method. The students were active in class participation and eager to do more effort like studying in a group. In spite of the challenging situation in SMA N 1 Banda Aceh, this method had successfully engaged the students to learn and improve their competitive debate skills, especially the argumentation. The students highly believed that this learning method was interesting and comfortable. This response was expected as the students were given much freedom to determine which song they want to analyse and deep and repeated explanation by the teacher reduced the students' anxiety.

2. Making AREL to be easily understood and familiar for the students. The students felt this method made them easier to comprehend AREL both inside $(\bar{x}=4.00 \mathrm{SD}=0.654)$ and outside $(\bar{x}=3.71 \mathrm{SD}=0.881)$ the competitive debate activities. Students who were taught with this method achieved high score as opposed to the students who were not taught with this method, even if they had much more experience in competitive debate. The difference in score was quite high between the students who attended most of the session compared to the students with low attendance. Qualitatively, the students' improvement could be observed based on the way they composed AREL, where after the revisiting and personal feedback, the students were able to make better AREL structure for song analysis.

3. Improving students' English proficiency by recognizing and analysing figurative meaning in the lyrics. Though the English proficiency was not tested in this study, most of the students agreed that this method helped them to improve their English proficiency, which included vocabularies $(\bar{x}=4.64 \mathrm{SD}=0.610)$ and figurative language $(\bar{x}=4.50$ $\mathrm{SD}=0.500)$ competencies.

\section{Recommendations}

The method of analysing English song with AREL can be used not only in competitive debate setting but also in classroom setting. AREL basically can be used in other academic activities (especially in speaking and writing, such as presentation and essay writing) so that it would be helpful for the students to have a comprehension on AREL. The hardest phase in learning AREL is in the basic understanding, thus revisiting the materials and giving personal feedback to each student is essential. Group activities in this learning method could give more ways for the students to catch up with the taught materials. Homework and tasks also help the students to keep up with the materials.

\section{References}

Adimarta, T. (2015). Grice's conversational cooperative principles in competitive debates. Magister Scientiae, 38(1), 108-122. Accessed on $15 \quad$ October 2018 from http://journal.wima.ac.id/index.php/Magister_Scientiae/article/view/787 
Aguirre, D., Bustinza, D., \& Garvich, M. (2016). Influence of songs in primary school students' motivation for learning English in Lima, Peru. English Language Teaching, 9(2), 178-191. Accessed on 15 October 2018 from http://www.ccsenet.org/journal/index.php/elt/article/view/56562

Agustina, L., \& Bahrani, B. (2016). The implementation of British parliamentary debating in Mulawarman Debate Society (MDS). Indonesian Journal of EFL and Linguistics, 1(1), 79-97. doi: 10.21462/ijefll.v1i1.6

Akerman, R., \& Neale, I. (2011). Debating the evidence: An international review of current situation and perception. Research Report: The English Speaking-Union. Accessed on 20 August 2017 from https://debate.uvm.edu/dcpdf/ESU Report debatingtheevidence FINAL.pdf

Alasmari, A., \& Ahmed, S. S. (2013). Using debate in EFL classes. English Language Teaching, 6(1), 147-152. Accessed on 15 October 2018 from http://doi.org/10.5539/elt.v6n1p147

Aleshtar, M. T., \& Dowlatabadi, H. (2014). Metaphoric competence and language proficiency in the same boat. Procedia-Social and Behavioral Sciences, 98(1), 1895-1904. Accessed on 20 August 2017 from https://doi.org/10.1016/j.sbspro.2014.03.620

AlOthman, F. H. M., \& Shuqair, K. M. (2013). The impact of motivation on English language learning in the Gulf states. International Journal of Higher Education, 2(4), 123-130. Accessed on 26 December 2018 from https://doi.org/10.5430/ijhe.v2n4p123

ASEAN Secretariat News. (2016). ASEAN priorities youth development index in work plan. Accessed on 21 August 2017 from: http://asean.org/asean-prioritises-youth-development-index-in-work-plan/

Berman, J. D., McCormack, M. C., Koehler, K. A., Connolly, F., Clemons-Erby, D., Davis, M. F., \& Curriero, F. C. (2018). School environmental conditions and links to academic performance and absenteeism in urban, midAtlantic public schools. International Journal of Hygiene and Environmental Health, 221(5), 800-808. Accessed on 20 August 2017 from https://doi.org/10.1016/j.ijheh.2018.04.015

Brookfield, S. D., \& Preskill, S. (2012). Discussion as a way of teaching: Tools and techniques for democratic classrooms. John Wiley \& Sons, New Jersey-USA.

Chen, Y. C., \& Lai, H. L. (2011). The effect of EFL learners' awareness and retention in learning metaphoric and metanymic expressions. Proceeding of the $25^{\text {th }}$ Pacific Asia Conference on Language, Information and Computation. Accessed on 15 October 2018 from http://aclweb.org/anthology/Y11-1058

Condon, M., \& Doody, O. (2012). Increasing student involvement and learning through using debate as an assessment. Nurse Education in Practice, 12(1), 232-237. Accessed on 15 October 2018 from: http://doi.org/10.1016/j.nepr.2012.03.002

Conesa, I. M. G., \& Rubio, A. D. J. (2015). The use of rhymes and songs in the teaching of English in primary $\begin{array}{llllr}\text { education. } & \text { Docencia } & e & \text { Investigación. } & 25(2),\end{array}$ https://revista.uclm.es/index.php/rdi/article/download/1008/837

Djamarah, S. B., \& Zain, A. (2002). StrategiBelajarMengajar. RinekaCipta, Jakarta.

Doiz, A., \& Elizari, C. (2013). Metaphoric competence and the acquisition of figurative vocabulary in foreign language learning. ELIA, 13(1), 47-82. Accessed on 15 October 2018 from http://dx.doi.org/10.12795/elia.2013.i13.02

Finn, B., Thomas, R., \& Rawson, K. A. (2017). Learning more from feedback: Elaborating feedback with examples enhances concept learning. Learning and Instruction. https://doi.org/10.1016/j.learninstruc.2017.08.007

Hariyanto, H. (2017). The analysis of figurative language used in the lyric of firework by Katy Perry (a study of semantic). English Education: Jurnal Tadris Bahasa Inggris, 10(1), 46-60. Accessed on 15 October 2018 from http://ejournal.radenintan.ac.id/index.php/ENGEDU/article/view/874

Hoogerheide, V., Loyens, S. M. M., \& van Gog, T. (2016). Learning from video modelling examples: does gender matter? Instructional Science, 44(1), 69-86. 
Husnawadi, H., \& Syamsudani, S. (2016). The role of English debating tournament in the face of ASEAN economic community (AEC). DinamikaIlmu, 16(1), 119-113.

Iqhrammullah, M., \& Zuelda, N. (2017). The landscape of competitive debate in Aceh: Benefit, achievement and challenges. Proceeding of The $1^{\text {st }}$ International Conference on Language, Literature, and Teaching (IcoLLiT). Accessed on 20 August 2017 from https://publikasiilmiah.ums.ac.id/handle/11617/8850

Kakkar, S. B. (1993). Educational psychology. PHI Learning Private, New Delhi.

Kuśnierek, A. (2016). The role of music and songs in teaching English vocabulary to students. World Scientific News, 43(1), 1-55. Accessed on 15 October 2018 from http://www.worldscientificnews.com/wpcontent/uploads/2015/10/WSN-431-2016-1-55.pdf

Lee, L., \& Li, T. Y. (2016). The impact of music activities in a multi-sensory room for children with multiple disabilities on developing positive emotions: a case study. Journal of the European Teacher Education Network, 11(1), 1-12.

Mahdiloo, A., \& Izadpanah, S. (2017). The impact of humorous movie clips on better learning of English language vocabulary. IJREE, 2(2), 16-29. Accessed on 26 December 2018 from https://doi.org/10.18869/acadpub.ijree.2.2.16

Mangal, S. K. (2002). Advanced educational psychology (second edition). PHI Learning Private, New Delhi.

Marliani, H. (2018). The analysis of figurative language in Harris J. Songs. Skripsi thesis, UIN Ar-Raniry Banda Aceh. Accessed on 15 October 2018 from https://repository.arraniry.ac.id/2965/1/HENNY\%20MARLIANI.pdf

Mehrvarz Bahambari, N., \& Rahimy, R. (2016). School general English achievement and group-work: An investigation among Iranian junior high school students TT. IJREE, 1(1), 43-50. Accessed on 26 December 2018 from http://ijreeonline.com/article-1-28-en.html

Millington, N. T. (2011). Using songs effectively to teach English to young learners. Language Education in Asia, 2(1), 134-141.

Muhammadin, F. M., Sekarsari, V., Pido, M. F., Puteri, K. H., Fadillah, R. D., Destia, K., Wicaksono, M. R., Hanif, I., Hindarto, T., Supriono, D., \& Harisa, M. (2014). Handbook for Competitive Debating: Asian Parliamentary Format. Jogja Debating Forum, Yogyakarta.

Nadera, B. (2015). Promoting student motivation in EFL classroom: Through extended music education. Procedia Social and Behavioral Sciences, 199(1), 368-371. Accessed on 26 December 2018 from https://doi.org/10.1016/j.sbspro.2015.07.520

Parcher, J. (1998). The value of debate: Adapted from the report of the philodemic debate society. Accessed on 20 August 2017 from http://www.debateleaders.org/The\%20Value\%20of\%20Debate.htm

Phisutthangkoon, K., \& Panich, M. (2016). Effectiveness of English song activities on vocabulary learning and retention. Proceeding of The European Conference on Language Learning 2016. Accessed on 20 August 2017 from http://papers.iafor.org/papers/ecl12016/ECLL2016_28332.pdf

Pradana, S. A. (2017). Using debate to enhance students' speaking ability as their character building. English Education: Jurnal Tadris Bahasa Inggris, 10(1), 149-163. Accessed on 15 October 2018 from http://ejournal.radenintan.ac.id/index.php/ENGEDU/article/view/881

Ramlan, F. A., Kassim, N. M., Pakirisamy, S., \& Selvakumar, V. (2016). The impact of debates as a teaching strategy in the classroom to medical students. e-Academia Journal UiTMT, 2(5), 194-203. Accessed on 15 October 2018 from http://journale-academiauitmt.uitm.edu.my/v2/images/vol5issue2/CRPID53THEIMPACTOFDEBATES.pdf

Renninger, K. A., Sansone, C., \& Smith, J. L. (2004). Love of learning. In C. Peterson \& M. E. P. Seligman (Eds.), Character strengths and virtues: A handbook and classification (pp. 161-179). New York: Oxford University Press. 
Rohmatika, A., \& Syamsuddin, R. (2014). The use of AREL in argumentation at English debating club of STKIP PFRI Ponorogo. Dinamika Ilmu, 2(14), 162-175. Accessed on 15 October 2018 from https://journal.iainsamarinda.ac.id/index.php/dinamika ilmu/article/view/1

Shen, C. (2009). Using English songs: an enjoyable and effective approach to ELT. English Language Teaching, 2(1), 88-94. Accessed on 15 October 2018 from https://files.eric.ed.gov/fulltext/EJ1082242.pdf

Simbolon, N. D., \& Ginting, A. (2013). Improving students' achievement in writing analytical exposition through debate technique. Journal of English Language Teaching of FBS UNIMED, 1(2), 1-14. Accessed on 15 October 2018 from http://jurnal.unimed.ac.id/2012/index.php/eltu/article/view/631

Sonnreich, T. (2012). Monash associationof debaters guideto debating: Tips, tactics and first principles. Accessed on 15 October 2018 from http://www.monashdebaters.com/downloads/Tim\%20Sonnreich's\%20Guide.pdf 